\title{
Detection of rainbow trout antibodies to infectious pancreatic necrosis virus by an immunoassay
}

\author{
P. F. Dixon ${ }^{1, *}$, J. de Groot $^{2, * *}$ \\ 'Ministry of Agriculture, Fisheries and Food, Directorate of Fisheries Research, Fish Diseases Laboratory, Weymouth, \\ Dorset DT4 8UB, United Kingdom \\ ${ }^{2}$ Department of Fish Culture and Fisheries, Wageningen Agricultural University, $6700 \mathrm{AH}$ Wageningen, The Netherlands
}

\begin{abstract}
An enzyme-linked immunosorbent assay (ELISA) for the detection of infectious pancreatic necrosis virus (IPNV) antibodies in rainbow trout Oncorhynchus mykiss was assessed. There was close agreement between the results of the ELISA and a neutralisation test for detecting IPNV antibody when fish sera were tested by both methods. The differences between the ELISA and virus neutralisation are most likely because antibodies against different virus epitopes reacted in the 2 techniques. The sample correlation coefficients of ELISA absorbance values and neutralisation titres for 2 different populations of fish were -0.42 and 0.78 . Reasons for those differences are discussed. Combined data from 4 different IPNV positive fish groups showed that virus was isolated from $29.9 \%(32 / 107)$ of the fish, whereas more than twice that number were antibody positive by the ELISA. All the virus positive fish were also antibody positive by the ELISA and/or neutralisation. Although the ELISA did not detect all virus positive individuals, it potentially has a role in detecting rainbow trout populations previously exposed to IPNV.
\end{abstract}

KEY WORDS: IPNV - ELISA - Antibody detection - Rainbow trout Immunoassay - Neutralisation

\section{INTRODUCTION}

It has been known for over 25 yr that rainbow trout Oncorhynchus mykiss produce antibody against infectious pancreatic necrosis virus (IPNV) (Wolf \& Quimby 1969), but over that time, there have been few reports of the use of screening rainbow trout for antibody against IPNV as an epidemiological tool (Yamamoto 1975. Wizigmann et al. 1983, Reisshauer \& Rapp 1984, Hoppe \& Wernery 1985, Ahne et al. 1986b, Bragg 1991). The screening method used in the majority of those reports was virus neutralisation, which is generally more labour intensive than virus isolation, and may explain why the routine screening of fish sera for neutralising antibody has not been used more extensively. The fluorescent antibody test has been employed to detect IPNV antibodies in rainbow trout sera

•E-mail: p.f.dixon@dfr.maff.gov.uk

- Present address: Birds Eye Walls, Martins Score, Lowestoft, Suffolk NR32 1JG, UK
(Ahne et al. 1986a, b) but even though it was more rapid and sensitive than virus neutralisation, it has not been widely used.

The virus used in the neutralisation test has to be a strain that will not be neutralised by normal trout serum. Jørgensen (1973) reported that sera from rainbow trout with no history of IPNV neutralised the virus, a finding confirmed by Dorson \& Kinkelin (1974), who showed that the component of the sera responsible for neutralisation had a sedimentation coefficient of $6 \mathrm{~S}$; normal sera possessing that component will be referred to as $6 \mathrm{~S}$ sera. Virus isolates that had been passaged in cell culture a low number of times were usually resistant to neutralisation by $6 \mathrm{~S}$ sera whilst those at a high passage number were usually neutralised by the sera (Dorson et al. 1975, 1978); resistance of IPNV isolates passaged in cell culture to neutralisation by $6 \mathrm{~S}$ sera could be selected for, or maintained by, the addition of $6 \mathrm{~S}$ sera to the culture medium (Hill \& Dixon 1977). IPNV isolates of different serotypes are neutralised by $6 \mathrm{~S}$ sera (Ahne 1980 , 
Kelly \& Nielsen 1985). There are at least 10 serotypes of IPNV in 2 serogroups, determined using rabbit antisera (Hill \& Way 1995), which also needs to be taken into account when undertaking antibody screening. Rainbow trout sera can discriminate between IPNV serotypes in neutralisation and fluorescent antibody tests, although some sera cross-react (to a lesser degree) with heterologous serotypes (Ahne et al. 1986b, Kelly \& Nielsen 1990). Each IPNV serotype has a restricted geographic distribution (B. J. Hill \& K. Way pers. comm.), which means that in areas where the IPNV serotypes present are known, antibody screening tests can be designed accordingly, although that may not permit detection of antibodies against new or newly introduced serotypes.

In recent years, there have been more published reports of the use of antibody screening as a measure of previous exposure of fish to pathogens, including viruses. The tests may be used for health screening, assessing the humoral response to a vaccine, or assessing the humoral response to an infection. Microneutralisation tests for detecting fish antibodies against viral pathogens have been developed (HattenbergerBaudouy et al. 1989, Dixon et al. 1994), but a greater number of immunoassays have been described for detecting such antibodies. They include those for detecting antibodies against viral haemorrhagic septicaemia virus (VHSV) (Cossarini-Dunier 1985, Olesen et al. 1991), infectious haematopoietic necrosis virus (IHNV) (Jørgensen et al. 1991, Ristow et al. 1993), spring viraemia of carp virus (SVCV) (Dixon et al. 1994), striped jack nervous necrosis virus (Mushiake et al. 1992) and infectious pancreatic necrosis virus (IPNV) in Atlantic salmon Salmo salar (Håvarstein et al. 1990). This report describes an enzyme-linked immunosorbent assay (ELISA) to detect rainbow trout antibody to IPNV, after both experimental and natural infections.

\section{MATERIALS AND METHODS}

Virus. IPNV strain $31 / 75$ (Sp serotype = serotype $A_{2 i}$ Hill \& Way 1995) (Dorson et al. 1975) was grown in BF2 cells, titrated and purified as previously described (Dixon \& Hill 1983a). Briefly, the purification procedure involved stirring a virus harvest with polyethylene glycol 6000 and sodium chloride for 16 h at $4{ }^{\circ} \mathrm{C}$, centrifuging the mixture at $1800 \times g$ for $1 \mathrm{~h}$, and then layering the resuspended pellet onto $15-45 \%$ linear sucrose gradients which were centrifuged at $45000 \times g$ for $2 h_{i}$ the opaque virus-containing band was harvested, diluted in buffer and centrifuged at $95000 \times \mathrm{g}$ for $1.5 \mathrm{~h}$, after which the virus pellet was resuspended in buffer. It was used in virus neutralisation tests (see below) and, at the passage number used, was not neutralised by rainbow trout serum having $6 \mathrm{~S}$ activity.

Antiserum to rainbow trout immunoglobulin. Rabbit antiserum (no. 966) was kindly provided by Dr $M$. Dorson, INRA, Jouy-en-Josas, France. It was purified and conjugated with alkaline phosphatase (hereafter called 966 conjugate) as described by Lorenzen \& Dixon (1991).

Fish sampling. Rainbow trout were obtained from commercial fish farms in England which had been regularly tested for IPNV at the Fish Diseases Laboratory (FDL), Weymouth. Different sources of fish were used: (1) 121 -yr-old fish that were survivors of an experimental IPNV infection (as described by Hill et al. 1980) initiated when they were 8 wk old; (2) 20 mixed fingerling, 1- and 2-yr-old tish trom an IPNV negative site (Site A); (3) 441 -yr-old fish from an IPNV positive site (Site B); (4) 18 mixed fingerling, 1 - and 2-yr-old fish from an IPNV positive site (Site C); and (5) 33 mixed fingerling, 1- and 2-yr-old fish from an IPNV positive site (Site D). Fish were transported to the laboratory, where they were anaesthetised with MS-222 (Sandoz) and bled from the caudal vessels. Blood from fish from sources 1, 2, 4 and 5 was collected in heparinised syringes, and the blood from fish from source 3 was collected in non-heparinised syringes, transferred to another container and allowed to clot overnight at $4^{\circ} \mathrm{C}$. After severing the spinal cord of each fish, pieces of liver, kidney, spleen and pancreas-caecae were removed and pooled. Different sterile instruments were used for each fish and each fish was individually tested for virus and antibody.

Sample processing. All centrifugation steps were done at $4^{\circ} \mathrm{C}$. Serum was removed from blood clots and clarified by centrifugation at $1000 \times g$ for $10 \mathrm{~min}$. Heparinised blood was centrifuged at $200 \times g$ for 15 min. The serum or plasma samples were divided into aliquots then tested immediately or stored at $-20^{\circ} \mathrm{C}$ until tested. The pelleted blood cells were washed twice in Hank's balanced salt solution (HBSS), diluted to $4 \mathrm{ml}$, overlaid onto a Percoll (Pharmacia Biotech) step gradient ( 1.065 and 1.080 densities) then centrifuged at $400 \times g$ for $40 \mathrm{~min}$. Leucocytes at the interface of the Percoll layers were harvested, diluted $1: 2$ in HBSS then centrifuged at $1000 \times \mathrm{g}$ for $10 \mathrm{~min}$ After removal of the supernatant, the cell pellet was frozen $\left(-20^{\circ} \mathrm{C}\right)$, thawed and diluted to $4 \mathrm{ml}$ in maintenance medium (MM) (Glasgow modification of Eagle's medium supplemented with $2 \%$ foetal calf serum) for virus isolation. Tissue samples were homogenised diluted 1:5 in MM containing a high level of antibiotics (MM-HLA) [1000 IU mi $\mathrm{m}^{-1}$ penicillin $\mathrm{G}$ (sodium salt) and $1 \mathrm{mg} \mathrm{ml}^{-1}$ streptomycin sulphate], clarified at $1500 \times \mathrm{g}$ for 15 min and then diluted with MM-HLA to a final dilution of 1:100 for virus isolation. 
Virus isolation. BF-2 cells were inoculated with the samples and incubated for $5 \mathrm{~d}$ at $15^{\circ} \mathrm{C}$. Cultures were frozen $\left(-20^{\circ} \mathrm{C}\right)$ then thawed; those not showing cytopathic effect (CPE) were passaged at a 1:10 dilution, whereas those showing CPE were passaged at 1:100. The cells were observed for a further $7 \mathrm{~d}$

Virus neutralisation. Serum or plasma samples were diluted in $\mathrm{MM}$ in full and half logarithmic (base 10) steps from $2 \times 10^{-2}$ to $2 \times 10^{-5}$ and mixed with an equal volume of MM containing approximately 200 plaqueforming units of IPNV and incubated at $20^{\circ} \mathrm{C}$ for $1 \mathrm{~h}$. Of this mixture, $200 \mu \mathrm{l}$ were adsorbed in triplicate to BF-2 cells on multiwell plates ( $34 \mathrm{~mm}$ diameter wells) for $1 \mathrm{~h}$, removed and replaced with $2 \mathrm{ml}$ of agarose overlay. After incubation for 3 to $4 \mathrm{~d}$ at $15^{\circ} \mathrm{C}$ the cells were fixed and stained (Dixon \& Hill 1983a) then the 50\% plaque neutralisation titre (50\% PNT) calculated. The $50 \%$ PNT is expressed in the text as a reciprocal value.

ELISA for IPNV antigen. The ultra-rapid ELISA described by Dixon \& Hill (1983b) was used to confirm the presence of IPNV in cell cultures exhibiting CPE. The absorbance at $405 \mathrm{~nm}\left(A_{405}\right)$ of the reaction product was read on a microplate reader (MR 7000, Dynatech). Each plate contained positive and negative controls. Positive samples had an $A_{405}$ at least twice that of the negative control.

ELISA for rainbow trout antibodies against IPNV. Microtitre plates were coated with purified IPNV $\left(0.8 \mu \mathrm{g} \mathrm{ml} \mathrm{m}^{-1}, 200 \mu \mathrm{l}\right.$ well $\left.{ }^{-1}\right)$ in carbonate buffer $\mathrm{pH} 9.6$ and incubated overnight at $25^{\circ} \mathrm{C}$. Following a wash in phosphate buffered saline (PBS), the wells were blocked with $1.5 \%$ bovine serum albumin (BSA) for $1 \mathrm{~h}$ at $37^{\circ} \mathrm{C}$. Plates were washed in PBS containing $0.05 \%$ Tween 20 (PBST), then plasma or serum samples were added in duplicate $\left(200 \mu \mathrm{l}\right.$ well $\left.\mathrm{l}^{-1}\right)$ and incubated for $1 \mathrm{~h}$ at $25^{\circ} \mathrm{C}$. The samples had been diluted $1: 10$ in PBST containing $1 \%$ BSA (PBST-BSA), then heated at $55^{\circ} \mathrm{C}$ for 25 min (modified from Ahne et al. 1986b) prior to their addition to the microtitre plates. Following a wash in PBST, the working dilution of 966 conjugate in PBST-BSA (1:700) was added (200 $\left.\mu \mathrm{l} \mathrm{well}{ }^{-1}\right)$ and incubated for $1 \mathrm{~h}$ at $25^{\circ} \mathrm{C}$. That working dilution had previously been determined by checkerboard titration against a range of known IPNV antibody positive and negative rainbow trout sera from different sources (as determined by their virus neutralising ability coupled with the disease history of the sources). The plates were again washed in PBST and then incubated with p-nitrophenol phosphate substrate, $200 \mu \mathrm{l} \mathrm{well}{ }^{-1}$, for $1 \mathrm{~h}$ at $37^{\circ} \mathrm{C}$. The reaction was stopped by the addition of $50 \mu \mathrm{l} \mathrm{well}{ }^{-1}$ of $3 \mathrm{M}$ sodium hydroxide and the absorbance of the hydrolysis product read as above. Each plate contained positive and negative controls. See 'Results' for determination of the positive-negative cutoff point.
Statistical analysis. Minitab (Minitab Inc.) or Excel (Microsoft Corporation) computer software was used for statistical analysis.

\section{RESULTS}

\section{Antibody ELISA positive-negative cut-off point}

IPNV was not isolated from tissues or leucocytes of rainbow trout from Site A (no history of IPN disease) and so the fish from that site were considered to be truly IPNV negative. The mean $\left( \pm \mathrm{SE}\right.$ ) $A_{405}$ value of plasma was $0.097( \pm 0.013)$, range 0.078 to 0.130 . For subsequent assays the positive threshold was calculated as the greater $A_{405}$ value of either 0.2 (twice the above mean value, rounded up), or twice the plate negative control $A_{405}$ value. In practice, the former method was used for all data presented here, as the latter value was always less than 0.2.

\section{Antibody in experimentally infected fish}

All of the plasma samples from experimentally infected fish contained IPNV neutralising antibody, with 50\% PNTs ranging from 700 to 40000 . All the plasma samples were also antibody positive by the ELISA (Table 1). IPNV was isolated from 8 of the tissue extracts, but was not isolated from any of the leucocyte samples. There was no correlation between $50 \%$ PNT and ELISA $A_{405}$ value (sample correlation coefficient, $\left.r_{1}=-0.42\right)$; there was also no association between whether or not IPNV was isolated and $50 \%$ PNT or ELISA $A_{405}$ value.

Table 1. $50 \%$ PNTs, ELISA $A_{405}$ values and virus isolation results of experimentally infected fish.

\begin{tabular}{|cccc|}
\hline Fish no. & $A_{405}$ value & $\begin{array}{c}50 \% \text { PNT } \\
\left(\times 10^{3}\right)\end{array}$ & $\begin{array}{c}\text { IPNV isolated } \\
\text { (tissues) }\end{array}$ \\
\hline 1 & 0.495 & 14.0 & - \\
2 & 0.298 & 17.0 & + \\
3 & 0.306 & 5.0 & + \\
4 & 0.352 & 40.0 & + \\
5 & 0.488 & 5.0 & + \\
6 & 1.068 & 0.7 & - \\
7 & 0.482 & 10.0 & + \\
8 & 0.412 & 3.3 & + \\
9 & 0.660 & 10.0 & + \\
10 & 0.796 & 7.7 & - \\
11 & 0.517 & 5.0 & + \\
12 & 0.511 & 6.7 & \\
& & & \\
a.Positive threshold: 0.2 & & \\
\hline
\end{tabular}


Table 2. $50 \%$ PNTs, ELISA $A_{405}$ values and virus isolation results of fish from a virus positive site (Site $B$ )

\begin{tabular}{|c|c|c|c|c|}
\hline Fish no. & $A_{405}$ value & $\begin{array}{l}\text { ELISA } \\
\text { antibody } \\
\text { positive }\end{array}$ & $\begin{array}{c}50 \% \text { PNT } \\
\left(\times 10^{3}\right)\end{array}$ & $\begin{array}{c}\text { IPNV } \\
\text { isolated } \\
\text { (tissues) }\end{array}$ \\
\hline 1 & 0.410 & + & $<0.1$ & + \\
\hline 2 & 0.505 & + & 1.9 & + \\
\hline 3 & 0.248 & + & 2.8 & - \\
\hline 4 & 0.768 & + & 8.0 & - \\
\hline 5 & 0.209 & + & $<0.1$ & - \\
\hline 6 & 0.087 & - & 2.0 & + \\
\hline 7 & 0.391 & + & 1.4 & + \\
\hline 8 & 0.209 & + & $<0.1$ & - \\
\hline 9 & 0.185 & - & 2.4 & + \\
\hline 10 & 0.720 & + & 4.0 & - \\
\hline 11 & 0.176 & - & $<0.1$ & - \\
\hline 12 & $0.1 \pm 6$ & & $<0.1$ & \\
\hline 13 & 0.144 & - & $<0.1$ & - \\
\hline 14 & 0.152 & - & $<0.1$ & - \\
\hline 15 & 0.164 & - & $<0.1$ & - \\
\hline 16 & 0.202 & + & $<0.1$ & - \\
\hline 17 & 0.136 & - & $<0.1$ & - \\
\hline 18 & 0.079 & - & $<0.1$ & - \\
\hline 19 & 0.380 & + & 1.0 & - \\
\hline 20 & 0.605 & + & 5.8 & + \\
\hline 21 & 0.178 & - & $<0.1$ & - \\
\hline 22 & 0.129 & - & $<0.1$ & - \\
\hline 23 & 0.463 & + & 4.5 & - \\
\hline 24 & 0.234 & + & 1.3 & - \\
\hline 25 & 0.458 & + & 1.1 & - \\
\hline 26 & 0.457 & + & 2.6 & - \\
\hline 27 & 0.089 & - & $<0.1$ & - \\
\hline 28 & 0.246 & + & 1.1 & - \\
\hline 29 & 0.141 & - & $<0.1$ & - \\
\hline 30 & 0.176 & - & $<0.1$ & - \\
\hline 31 & 0.119 & - & $<0.1$ & - \\
\hline 32 & 0.781 & + & 9.5 & + \\
\hline 33 & 0.193 & - & $<0.1$ & - \\
\hline 34 & 0.199 & - & $<0.1$ & - \\
\hline 35 & 0.611 & + & 6.8 & - \\
\hline 36 & 0.256 & + & 3.5 & + \\
\hline 37 & 0.237 & + & 1.3 & - \\
\hline 38 & 0.176 & - & $<0.1$ & - \\
\hline 39 & 0.072 & - & $<0.1$ & - \\
\hline 40 & 0.442 & + & 2.8 & - \\
\hline 41 & 0.516 & + & 4.7 & - \\
\hline 42 & 0.158 & - & $<0.1$ & - \\
\hline 43 & 0.244 & + & 3.6 & - \\
\hline 44 & 0.355 & + & 9.4 & + \\
\hline
\end{tabular}

\section{Antibody in fish from Site B}

Of the serum samples from fish from Site B (IPNV positive site) $50 \%(22 / 44)$ contained IPNV neutralising antibodies and $54.5 \%(24 / 44)$ were positive by the ELISA using the positive threshold of 0.2 (Table 2). Three fish (nos. 5, 8 and 16) were only just ELISA positive using that threshold value all of those fish were negative for neutralising antibody and for virus. If those fish are considered to be ELISA negative, the number of ELISA positive fish reduces to $47.7 \%$ $(21 / 44)$. There was a close correspondence between the results of the 2 antibody detection methods (Table 3), and a greater correlation between ELISA $A_{450}$ values and $50 \%$ PNTs $(r=0.78)$ compared with the experimentally infected fish. Only $24.5 \%$ (9/44) of the fish were positive for IPNV [confirmed as $\mathrm{Sp}\left(\mathrm{A}_{2}\right)$ serotype], and all virus positive fish were also antibody positive by ELISA and/or 50\% PNT (Table 3).

\section{ELISA antibody detection in fish from Sites C and D}

The ELISA $A_{405}$ values for plasma samples from Sites $\mathrm{C}$ and D (IPNV positive sites) and virus isolation results are shown in Table $4 ; 50 \%$ PNTs of these samples were not measured. No virus was isolated from the leucocyte extracts from fish from either site. None of the 3 2 -yr-old fish from Site $\mathrm{C}$ were virus positive, but virus was isolated from the other 2 age groups; antibody positive fish were found in all 3 age groups. Conversely, only the 2 -yr-old fish from Site $D$ were virus positive but again IPNV antibody was found in all 3 age groups. All virus positive fish from both sites were also antibody positive. The viruses isolated from both sites were $\operatorname{Sp}\left(\mathrm{A}_{2}\right)$ serotype.

\section{DISCUSSION}

An immunoassay for the detection of IPNV antibody in rainbow trout was assessed. There was close agreement between sera or plasma that were antibody positive by the ELISA and those that had neutralising anti-

Table 3. Comparison (number of fish) of the ELISA and 50\% PNT methods for detecting IPNV antibody in serum with isolation of virus from tissues of the same naturally infected rainbow trout from a virus positive site (Site $B$ )

\begin{tabular}{|c|c|c|c|c|c|}
\hline & $\begin{array}{l}\text { ELISA positive, } \\
50 \% \text { PNT positive }\end{array}$ & $\begin{array}{l}\text { ELISA negative, } \\
50 \% \text { PNT positive }\end{array}$ & $\begin{array}{l}\text { ELISA positive, } \\
50 \% \text { PNT negative }\end{array}$ & $\begin{array}{l}\text { ELISA negative, } \\
50 \% \text { PNT negative }\end{array}$ & Total \\
\hline Virus positive & 6 & 2 & 1 & 0 & 9 \\
\hline Virus negative & 14 & 0 & $3^{\mathrm{a}}$ & 18 & 35 \\
\hline Total & 20 & 2 & 4 & 18 & 44 \\
\hline
\end{tabular}


Table 4. ELISA $A_{405}$ values and virus isolation results of fish from 2 IPNV positive sites (Sites C and D)

\begin{tabular}{|c|c|c|c|c|c|}
\hline Site & Fish no. & $\begin{array}{l}\text { Fish } \\
\text { age }^{a}\end{array}$ & $\begin{array}{c}A_{405} \\
\text { value }\end{array}$ & $\begin{array}{l}\text { Antibody } \\
\text { positive }^{b}\end{array}$ & $\begin{array}{c}\text { IPNV } \\
\text { isolated } \\
\text { (tissues) }\end{array}$ \\
\hline C & 1 & $2+$ & 0.370 & + & - \\
\hline $\mathrm{C}$ & 2 & $2+$ & 0.196 & - & - \\
\hline C & 3 & $2+$ & 0.136 & - & - \\
\hline$c$ & 4 & $1+$ & 0.404 & + & - \\
\hline $\mathrm{C}$ & 5 & $1+$ & 0.330 & + & - \\
\hline$c$ & 6 & $1+$ & 0.150 & - & - \\
\hline$C$ & 7 & $1+$ & 0.242 & + & + \\
\hline C & 8 & $1+$ & 0.243 & + & - \\
\hline$C$ & 9 & $1+$ & 0.316 & + & + \\
\hline C & 10 & $1+$ & 0.403 & + & + \\
\hline C & 11 & $1+$ & 0.254 & + & + \\
\hline C & 12 & $\mathrm{~F}$ & 0.449 & + & - \\
\hline C & 13 & $\mathrm{~F}$ & 0.458 & + & + \\
\hline C & 14 & $\mathrm{~F}$ & 0.304 & + & t. \\
\hline$c$ & 15 & $\mathrm{~F}$ & 0.239 & + & + \\
\hline C & 16 & $\mathrm{~F}$ & 0.273 & + & + \\
\hline C & 17 & $\mathrm{~F}$ & 0.400 & + & + \\
\hline $\mathrm{C}$ & 18 & $F$ & 0.538 & + & + \\
\hline $\mathrm{D}$ & 1 & $2+$ & 0.374 & + & + \\
\hline$D$ & 2 & $2+$ & 0.453 & + & + \\
\hline D & 3 & $2+$ & 0.340 & + & + \\
\hline $\mathrm{D}$ & 4 & $2+$ & 0.221 & + & + \\
\hline $\mathrm{D}$ & 5 & $2+$ & 0.306 & + & + \\
\hline D & 6 & $1+$ & 0.294 & + & - \\
\hline D & 7 & $1+$ & 0.226 & + & - \\
\hline D & 8 & $1+$ & 0.220 & + & - \\
\hline D & 9 & $1+$ & 0.224 & + & - \\
\hline $\mathrm{D}$ & 10 & $1+$ & 0.285 & + & - \\
\hline $\mathrm{D}$ & 11 & $1+$ & 0.312 & + & - \\
\hline D & 12 & $1+$ & 0.342 & + & - \\
\hline$D$ & 13 & $1+$ & 0.244 & + & - \\
\hline$D$ & 14 & $1+$ & 0.235 & + & - \\
\hline $\mathrm{D}$ & 15 & $1+$ & 0.218 & + & - \\
\hline $\mathrm{D}$ & 16 & $1+$ & 0.159 & - & - \\
\hline $\mathrm{D}$ & 17 & $1+$ & 0.205 & + & - \\
\hline $\mathrm{D}$ & 18 & $1+$ & 0.156 & - & - \\
\hline$D$ & 19 & $1+$ & 0.148 & - & - \\
\hline $\mathrm{D}$ & 20 & $1+$ & 0.143 & - & - \\
\hline D & 21 & $1+$ & 0.173 & - & - \\
\hline $\mathrm{D}$ & 22 & $1+$ & 0.118 & - & - \\
\hline D & 23 & $1+$ & 0.139 & - & - \\
\hline D & 24 & $1+$ & 0.157 & - & - \\
\hline D & 25 & $\mathrm{~F}$ & 0.230 & + & - \\
\hline D & 26 & $\mathrm{~F}$ & 0.229 & + & - \\
\hline $\mathrm{D}$ & 27 & $\mathrm{~F}$ & 0.213 & + & - \\
\hline $\mathrm{D}$ & 28 & $F$ & 0.206 & + & - \\
\hline D & 29 & $\mathrm{~F}$ & 0.308 & + & - \\
\hline D & 30 & $\mathrm{~F}$ & 0.263 & + & - \\
\hline D & 31 & $\mathrm{~F}$ & 0.404 & + & - \\
\hline $\mathrm{D}$ & 32 & $F$ & 0.217 & + & - \\
\hline $\mathrm{D}$ & 33 & $F$ & 0.273 & + & - \\
\hline
\end{tabular}

body (Tables $1 \& 2$ ). However the correlation between $A_{405}$ value and $50 \%$ PNT differed for the 2 groups of fish tested by both methods. There was a negative correlation $(\mathrm{r}=-0.42)$ for plasma from experimentally infected fish, but a positive correlation ( $\mathrm{r}=0.78$ ) for serum from naturally infected fish. The fish were of a similar age, but had been obtained from different sources and held under different conditions (fish farm or laboratory) as well as having been infected in different ways and most likely at different times. The sample sizes were also different (12 experimentally infected fish and 44 naturally infected fish). It is not known which, if any, of these factors is responsible for the differences observed; testing sera from one group of fish and testing plasma from the other group would not account for the differences (authors' unpubl. data). Ristow et al. (1993) reported a significant correlation between ELISA and 50\% PNT for antibody against IHNV in experimentally infected rainbow trout.

Two sera from fish from Site B were ELISA negative but $50 \%$ PNT positive, whereas 4 sera were ELISA positive but $50 \%$ PNT negative. We are confident that the $50 \%$ PNT detected neutralising antibody rather than the non-specific $6 \mathrm{~S}$ factor as the test virus was known to be resistant to neutralisation by normal rainbow trout sera under conditions in which a 6 S-sensitive virus was neutralised (data not shown). This disparity between virus neutralisation and other antibody detection methods has been reported previously in assays to detect fish antibodies against IPNV (Ahne et al. 1986b), SVCV (Dixon et al. 1994), VHSV (CossariniDunier 1985, Jørgensen et al. 1991, Olesen et al. 1991) and IHNV (LaPatra et al. 1993, Ristow et al. 1993), These results suggest that, as with rhabdoviruses (Olesen et al. 1991, Dixon et al. 1994), the 2 methods are detecting different antibodies against IPNV. It is known from studies with monoclonal antibodies against IPNV that there are specific neutralisation epitopes (Caswell-Reno et al. 1986, Lecomte et al. 1992, Shankar \& Yamamoto 1994, Frost et al. 1995); hence neutralising antibody will only bind to those epitopes, whereas antibody reacting in the ELISA may bind to those and to other epitopes. There will be different clones of lymphocytes in the fish producing neutralising antibody which is specific for different IPNV epitopes, and it is possible that not all of the clones will produce antibody which reacts in the ELISA. Likewise, other antibodies which react in the ELISA will not react in the neutralisation test. The proportions of the different antibody types in certain fish sera may be such that they will only be identified by one of the methods. That may have a bearing on whether there is a correlation between ELISA $A_{405}$ value and $50 \%$ PNT; such positive correlation as was observed in this study may not reflect the same antibody molecules reacting in each test, rather a reflection of the overall level of total antibody in the sera.

The criterion for a serum being ELISA positive was that it should have an $A_{405}$ value greater than 0.2 . That 
value was twice the average $A_{405}$ value of sera from an IPNV-negative site. It is inevitable that $A_{405}$ values of some test sera will be close to the positive threshold and that was seen in sera from Site B (Table 2) where 2 sera had $A_{405}$ values of 0.209 and 1 serum had an $A_{405}$ value of 0.202 . As those sera were also neutralising antibody negative and the fish were virus negative, it could be argued that those sera were false positives in the ELISA. However, reasons for non-agreement of ELISA and neutralisation results have been discussed above; note also that fish no. 1 from Site B was a definite ELISA positive, but was neutralising antibody negative. A new positive threshold of 0.22 could be set (twice the sum of the average $A_{405}$ value and its standard error of sera from the IPNV-negative site) which would make the 3 borderline positive sera from Site B ELISA negative without affecting the ELISA status of any other sera from that site. If that revised positive threshold is also applied to sera from Sites C and D, there is no change in the number of ELISA antibody positive fish at Site C. However, 6 fish at Site D (nos. 8 , 15, 17,27, 28 and 32) would become ELISA antibody negative. All of those fish were virus negative. Fish no. 4 from Site D, a virus positive fish, would become borderline ELISA antibody positive $\left(A_{405}\right.$ value 0.221$)$. Whatever positive threshold is set, it is necessary to be circumspect about borderline positive results particularly if they are the only positive results obtained.

At each of Sites C and D, 3 different age groups of fish were tested, although unfortunately the numbers of 2 -yr-old fish were low. Specific antibody was detected by the ELISA in each age group at each site (Table 4). The results of virus isolation from those fish do not conform to any pattern, particularly with regard to Site D. At Site C, there were both antibody positive and virus positive fish in the fingerling and 1 -yr-old groups; $1 / 32$-yr-old fish was antibody positive, but none were virus positive. No significance can made of the results of the 2 -yr-old fish because of the small sample size. In contrast, at Site D all 9 fingerling fish ( 6 using the positive threshold of 0.22 ), 11/19 1 -yr-old fish ( 8 using the positive threshold of 0.22 ) and all 5 2 -yr-old fish were antibody positive, but only the 2 -yrold fish had detectable virus. Several previous studies have shown that IPNV neutralising antibody can be detected in virus negative trout (Wizigmann et al. 1983, Reisshauer \& Rapp 1984, Hoppe \& Wernery 1985, Mangunwiryo \& Agius 1988) although the extent of any neutralisation of virus by $6 \mathrm{~S}$ serum in those studies is unknown, and Hattenberger-Baudouy et al. (1989) reported a similar result for IHNV. In this study, differences in the sensitivity of the cells to infection with IPNV should not have been a reason why IPNV was only isolated from the 2-yr-old fish at Site D, as the virus isolation work for fish from that site was done on one occasion with the same cells. Any virus in the fingerling and 1-yr-old fish may have been below the level of detection (note that we find the BF-2 cell line the most sensitive for isolating IPNV, authors' unpubl. data), may have comprised an unusually high level of defective interfering particles (Nicholson \& Dexter 1975), may have been present as non-infectious immune complexes, may have been present in organs not tested (although the organs tested are regarded as the best source of IPNV, see McAllister 1993), or may have been eliminated from the fish. It is not known why the 2 -yr-old fish should differ from the other 2 age groups, but the fact that they were of different age groups meant that they contracted the virus at different times, and were kept at different locations on the site. Consequently, differences between the age groups are likely.

It was not the intention in this study to compare different methods of virus isolation, but in addition to isolation of IPNV from tissues, isolation of the virus from leucocytes was attempted using fish from 4 of the 5 sites tested, a total of 79 individual fish. Virus was not isolated from any of the leucocyte samples tested; however, 20 of the samples did come from fish on an IPNV negative site. IPNV has been isolated from trout leucocytes in other studies by co-cultivation (Yu et al. 1982, Ahne \& Thomsen 1986, Rodriguez Saint-Jean 1991), or after sonication (McAllister et al. 1993); such methods for isolating virus from leucocytes may be more sensitive than that used in this study .

Antibody detection was more sensitive than virus isolation as a means of determining previous exposure of the fish to IPNV. Combining the data from the experimentally infected fish and those from the IPNV positive sites, virus was isolated from the tissues of $29.9 \%(32 / 107)$ of the fish whereas antibody was detected by the ELISA in $71.0 \%(76 / 107)$ of the fish (or $62.6 \%, 67 / 107$, based on the positive threshold of 0.22 ). Possible reasons for that difference have already been discussed. In a proportion of the fish it is likely that virus had been eliminated and residual antibody was measured. The ELISA detected specific antibody in fish from all 3 IPNV positive sites and so it has potential to be used in health screening programmes to determine past exposure to the virus (but not necessarily current presence of virus); however, it must be noted that the number of different sites tested was small. All of the fish that had isolatable virus were positive for antibody. Of the 17 virus positive fish that were tested by both antibody detection methods, 15 were positive by the ELISA, and 16 were positive by the $50 \%$ PNT There are not enough data to determine whether one antibody detection method is more sensitive than the other, but it is clear that neither method alone can be used to forecast which individual fish will have isolatable virus. 
The ELISA method for detection of rainbow trout antibodies to IPNV makes screening of large numbers of samples possible and has the benefits of economy, speed and ease of use. Further evaluation will determine whether ELISA antibody testing could replace virus isolation as a means of assessing exposure of rainbow trout populations to IPNV. The ELISA could also be used to measure the humoral response of fish to an IPNV vaccine and so provide a rapid means of detecting responders, although there would be no indication as to whether the fish are protected. However, extrapolating from the results presented here on response to infectious virus, it is possible that on an individual fish basis, some responders to a vaccine may be missed

The IPNV isolate used as antigen in the ELISA was of the $\operatorname{Sp}\left(\mathrm{A}_{2}\right)$ serotype, which is the most frequently occurring serotype in rainbow trout in England and Wales (the source of fish to be tested for antibody should the ELISA be used routinely at FDL); the Ab serotype (serotype $A_{3}$; Hill \& Way 1995) also occurs in England and Wales, but infrequently (1 or 2 isolations in several years). It is not known whether rainbow trout antibodies against $\mathrm{Ab}\left(\mathrm{A}_{3}\right)$ serotype virus would react in this ELISA, but Atlantic salmon antibodies against the IPNV N1 strain did not react, or reacted only at a low level with other IPNV serotypes in an indirect ELISA, although there were differing results in a competition ELISA using the same serum (Håvarstein et al. 1990). If IPNV serotypes do not cross react to any significant degree in the ELISA, antigens of relevant serotypes would need to be incorporated into the assay. Non-specific reactions caused by the presence of antibodies against other pathogens may occur in serological tests, but the prevalence of such reactions in the ELISA, if they occur at all, will only be known after further trials of the method. Work is in progress to determine the limitations of the ELISA.

Acknowledgements. $H$. de G. was partially funded by the British Council.

\section{LITERATURE CITED}

Ahne W (1980) Vorkommen des Virus der infektiösen Pankreasnekrose der Forellen (IPN) bei verschiedenen Fischarten. Berl Münch Tierärztl Wschr 93:14-16

Ahne W. Delventhal H, Kohlmeyer G. Thomsen I (1986a) Nachweis von IPNV-Antikörpern in Forellenseren mit der indirekten Immunofluoreszenztechnik. J Vet Med B 33: $145-148$

Ahne W, Kohlmeyer G, Thomsen I (1986b) lnfektiöse Pankreasnekrose der Forellen (IPN): Vorkommen von Antikörpern gegenüber IPNV-Ab, -He und -Sp in Salmonidenseren in der Bundesrepublik Deutschland. Tierärztl Umsch 41:541-547

Ahne W, Thomsen I (1986) Infectious pancreatic necrosis: detection of virus and antibodies in rainbow trout IPNV- carrier (Salmo gairdneri). J Vet Med B 33:552-554

Bragg RR (1991) Health status of salmonids in river systems in Natal. II. Isolation and identification of viruses. Onderstepoort J Vet Res 58:63-65

Caswell-Reno P, Reno PW. Nicholson BL (1986) Monoclonal antibodies to infectious pancreatic necrosis virus: analysis of viral epitopes and comparison of different isolates. J Gen Virol 67:2193-2205

Cossarinı-Dunier M (1985) Indirect enzyme-linked immunosorbent assay (ELISA) to titrate rainbow trout serum antibodies against two pathogens: Yersinia ruckeri and Egtved virus. Aquaculture 49:197-208

Dixon PF, Hattenberger-Baudouy AM, Way K (1994) Detection of carp antibodies to spring viraemia of carp virus by a competitive immunoassay. Dis Aquat Org 19:181-186

Dixon PF, Hill BJ (1983a) Inactivation of infectious pancreatic necrosis virus for vaccine use. J Fish Dis 6:399-409

Dixon PF, Hill BJ (1983b) Rapid detection of infectious pancreatic necrosis virus (IPNV) by the enzyme-linked immunosorbent assay (ELISA). J Gen Virol 64:321-330

Dorson M, Castric J, Torchy C (1978) Infectious pancreatic necrosis virus of salmonids: biological and antigenic features of a pathogenic strain and of a non-pathogenic variant selected in RTG-2 cells. J Fish Dis 1:309-320

Dorson M, Kinkelin P de (1974) Nécrose pancréatique infectieuse des salmonidés: existence dans le sérum de truites indemnes d'une molécule $6 \mathrm{~S}$ neutralisant spécifiquement le virus. C R Acad Sci Paris Sér D 278:785-788

Dorson M, Kinkelin P de, Torchy C (1975) Virus de la nécrose pancréatique infectieuse: acquisition de la sensibilité au facteur neutralisant du sérum de truite après passages successifs en culture cellulaire. C" R Acad Sci Sér D 281. $1435-1438$

Frost P, Håvarstein LS, Lygren B, Ståhl S, Endresen C, Christie KE (1995) Mapping of neutralization epitopes on infectious pancreatic necrosis viruses. J Gen Virol 76 : $1165-1172$

Hattenberger-Baudouy AM, Danton M, Merle G, Torchy C, Kinkelin P de (1989) Serological evidence of infectious hematopoietic necrosis in rainbow trout from a French outbreak of disease. J Aquat Anim Health 1:126-134

Hăvarstein LS, Endresen C. Hjeltnes B, Christie KE, Glette J (1990) Specific immunoglobulins in serum from A.tlantic salmon, Salmo salar L., immunised with Vibrio salmonicida and infectious pancreatic necrosis virus. J Fish Dis 13: 101-111

Hill BJ, Dixon PF (1977) Studies on IPN virulence and immunization. Bull Off Int Epiz 87:425-427

Hill BJ, Dorson M, Dixon PF (1980) Studies on immunisation of trout against IPN. In: Ahne W (ed) Fish diseases. Third COPRAQ Session. Springer Verlag, Berlin, p 29-36

Hill BJ, Way K (1995) Serological classification of infectious pancreatic necrosis (IPN) virus and other aquatic birnaviruses. Ann Rev Fish Dis 5:55-77

Hoppe K, Wernery U (1985) Ergebnisse serologischer Untersuchungen zum Nachweis von Antikörpern gegen die Viren der infektiösen Pankreasnekrose (IPN), der viralen hämorrhagischen Septikämie (VHS) und der Fruhlingsvirämie (SVC) in Schleswig-Holstein sowie deren rechtliche Auswirkungen. Disch Tierärztl Wschr 92:172-174

Jørgensen PEV (1973) The nature and biological activity of IPN virus neutralizing antibodies in normal and immunized rainbow trout (Salmo gairdneri). Arch Ges Virusforsch 42:9-20

Jørgensen PEV, Olesen NJ, Lorenzen N, Winton JR, Ristow SS (1991) Infectious hematopoietic necrosis (IHN) and viral hemorrhagic septicemia (VHS): detection of trout 
antibodies to the causative viruses by means of plaque neutralization, immunofluorescence, and enzyme-linked immunosorbent assay. J Aquat Anim Health 3:100-108

Kelly RK, Nielsen O (1985) Inhibition of infectious pancreatic necrosis virus by serum from normal rainbow trout (Salmo gairdneri) in Canadian hatcheries. Fish Pathol 19:245-251

Kelly RK, Nielsen O (1990) Serological properties of neutralising antibodies induced by vaccination of rainbow trout with distinct strains of infectious pancreatic necrosis virus $\mathrm{J}$ Aquat Anim Health 2:56-60

LaPatra SE, Turner T, Lauda KA, Jones GR, Walker S (1993) Characterization of the humoral response of rainbow trout to infectious hematopoietic necrosis virus. J Aquat Anim Health 5:165-171

Lecomte J, Arella M, Berthiaume L (1992) Comparison of polyclonal and monoclonal antibodies for serotyping infectious pancreatic necrosis virus (IPNV) strains isolated in eastern Canada. J Fish Dis 15:431-436

Lurenzen K, Dixon PF (1991) Prevalence of antibodics to lym phocystis virus in estuarine flounder Platichthys flesus. Dis Aquat Org 11:99-103

Mangunwiryo $\mathrm{H}$, Agius $\mathrm{C}(1988)$ Studies on the carrier state of infectious pancreatic necrosis virus infections in rainbow trout, Salmo gairdneri Richardson. J Fish Dis 11. 125-132

McAllister PE (1993) Salmonid fish viruses. In: Stoskopf MK (ed) Fish medicine. WB Saunders Co, Philadelphia, p $380-408$

McAllister PE, Schill WB, Owens W, Hodge DL (1993) Determining the prevalence of infectious pancreatic necrosis virus in asymptomatic brook trout Salvelinus fontinalis: a study of clinical samples and processing methods. Dis Aquat Org 15:157-162

Mushiake $K$, Arimoto $M$, Furusawa $T$, Furusawa I, Nakai T, Muroga K (1992) Detection of antibodies against striped jack nervous necrosis virus (SJNNV) from brood stocks of striped jack. Nippon Suisan Gakkaishi 58:2351-2356

Responsible Subject Editor: F. M. Hetrick, College Park, Maryland, USA
Nicholson BL, Dexter R (1975) Possible interference in the isolation of IPN virus from carrier fish. $J$ Fish Res Bd Can 32: $1437-1439$

Olesen NJ, Lorerizen N, Jørgensen PEV (1991) Detection of rainbow trout antibody to Egtved virus by enzyme-linked immunosorbent assay (ELISA), immunofluorescence (IF), and plaque neutralization tests (50\% PNT). Dis Aquat Org 10:31-38

Reisshauer G, Rapp J (1984) Untersuchungen über Virusinfektionen bei Forellen in Südwürttemberg. Tierärztl Umsch 39:772-776

Ristow SS, Avila J de, LaPatra S, Lauda K (1993) Detection and characterization of rainbow trout antibody against infectious hematopoietic necrosis virus. Dis Aquat Org 15: $109-114$

Rodriguez Saint-Jean S, Pilar Vilas Minondo M, Angel Palacios M. Perez Prieto S (1991) Detection of infectious pancreatic necrosis in a carrier population of rainbow trout, Oncorhynchus mykiss (Richardson), by flow rytnmetry J Fish Dis 14:545-553

Shankar KM, Yamamoto T (1994) Epitope analysis of infectious pancreatic necrosis virus (IPNV) isolated from lake trout, Salvelinus namaycush (Walbaum), by monoclonal antibodies. J Fish Dis 17:471-482

Wizigmann G, Dangschat H, Baath C, Pfeil-Putzien C (1983) Untersuchungen über Virusinfektionen bei Süsswasserfischen in Bayern. Tierärztl Umsch 38:250-258

Wolf K, Quimby MC (1969) Infectious pancreatic necrosis: clinical and immune response of adult trouts to inoculation with live virus. J Fish Res Bd Can 26:2511-2516

Yamamoto Y (1975) Infectious pancreatic necrosis (IPN) virus carriers and antibody production in a population of rainbow trout (Salmo gairdneri). Can J Microbiol 21: $1343-1347$

Yu KKY, Macdonald RD, Moore AR (1982) Replication of infectious pancreatic necrosis virus in trout leucocytes and detection of the carrier state. J Fish Dis 5:401-410

Manuscript first received: November 5, 1995

Revised version accepted: March 6, 1996 